\title{
TEMPERATURE OBSERVATIONS IN THE WATER-OFF MUARA KARANG
}

\author{
by \\ KASTORO $^{1}$ and SOEJATNO BIROWO ${ }^{1}$
}

\begin{abstract}
During the period of March 1975 to February 1976 a survey was carried out in the water off Muara Karang, Jakarta Bay. Water temperature were slightly higher than those in the open sea, and showed a seasonal variation. The seasonal variation axe affected by meteorological conditions, incoming water from neighbouring seas, and by the land mass.
\end{abstract}

\section{INTRODUCTION}

A series of hydrological observation has been carried out from March 1975 to February 1976 with an interval of approximately one month in the water off Muara Karang, Jakarta Bay. Nine stations has been occupied. The hydrological work included the measurement of temperature and the determination of salinity, dissolved oxygen, and nutrient content of the sea water. This work is part of an extensive environmental study of this area conducted by Lembaga Oseanologi Nasional (National Institute of Oceanology). This paper will deal with results of temperature observations only.

\section{MATERIALS AND METHODS}

The studied area covers an area lying between latitudes $06^{\circ} 02^{\prime} \mathrm{S}$. and $06^{\circ} 07^{\prime} \mathrm{S}$., and longitudes $106^{\circ} 44^{\prime} \mathrm{E}$. and $106^{\circ} 49^{\prime} \mathrm{E}$. It is exactly north of Muara Karang River. The locations of the area and the positions of the hydrological stations are shown in Figure 1. As the depth range of this area is only 1 to $9 \mathrm{~m}$, only two water temperature measurements were made, i.e. of the surface layer $(0 \mathrm{~m})$ and of the sub-surface layer. $(1 \mathrm{~m}$ above the sea bottom). The temperature measurements were made by using reversing thermometers and were conducted during day time only (between $10 \mathrm{a} . \mathrm{m}$. to 15 p.m.). The affect of the altitude of the solar radiation to the whole observations can then be regarded as constant.

National Institute of Oceanology, Indonesian Institute of Sciences, Jakarta. 


\section{KASTORO \& SOEJATNO BIROWO}

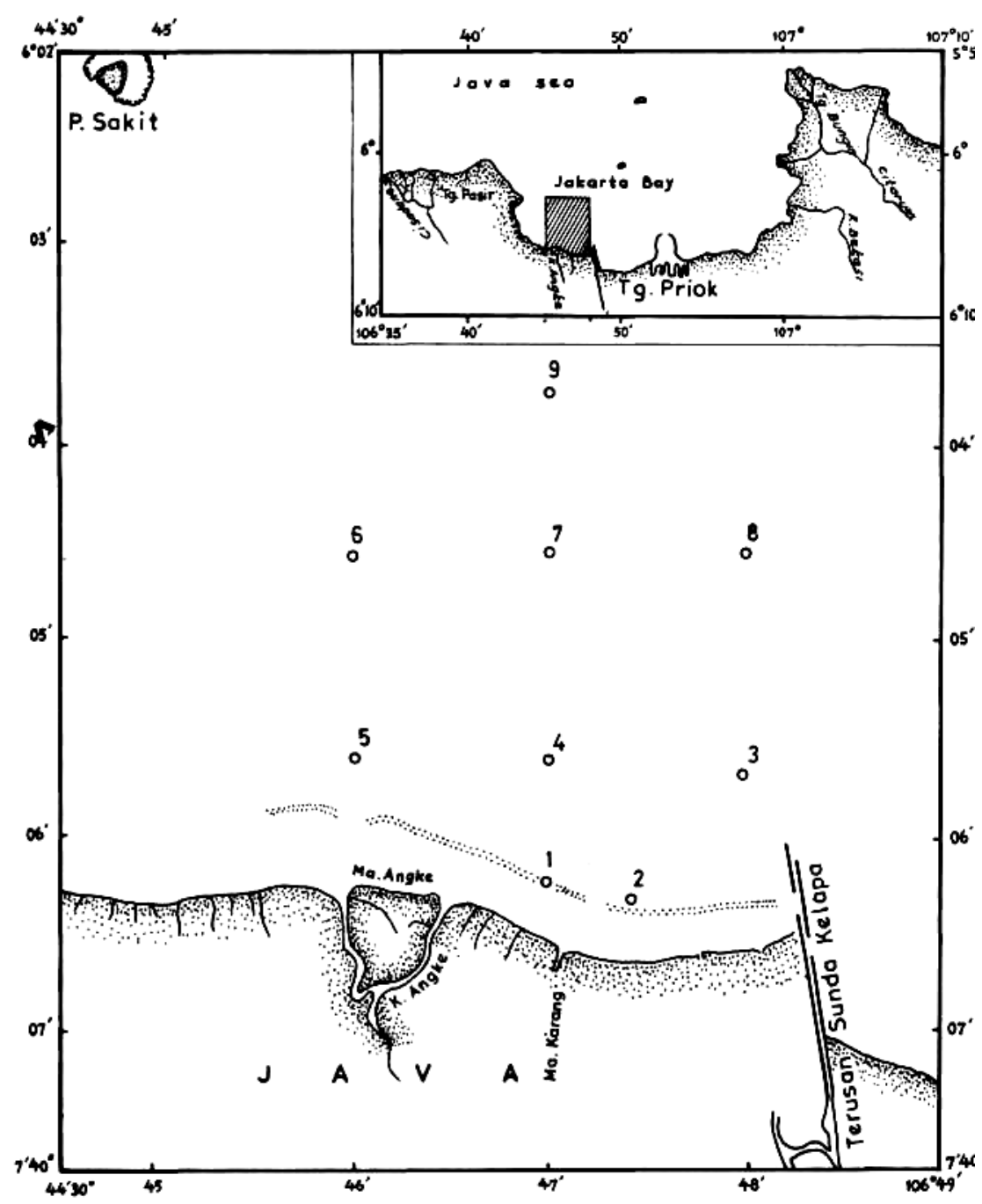

Figure 1. Locations of stations in the waters off Muara Karang 


\section{The monthly variation}

The monthly temperature variation from March 1975 to February 1976 of each station is shown graphically on Figure 2. It is apparent that the patterns of the monthly distribution of the temperature at the surface layer (solid line) and at the subsurface layer (dashed line) are identical. They also show two maxima and two minima.

The first maximum value recorded around May will fall slowly and reaches the first minimum value around July. From July the values are generally constant before rising again toward the second maximum in November. Then they fall off rapidly and reached the second minimum around January.

These patterns reveal that the temperature of high values occur during the first transitional period (March to May) and during the second transitional period (September to November). While the temperature of lower values occur during the east monsoon (June to August) and during the west monsoon (December to February).

\section{The horizontal distribution}

A three-monthly average value of each season is taken and the horizontal distribution representing the four respected seasons are shown on Figures 3-10. They show that the seasonal value at the surface layer vary from $30.0^{\circ}$ to $30.8^{\circ} \mathrm{C}$ in the first transitional period, from $29.6^{\circ}$ to $30.5^{\circ} \mathrm{C}$ in the east monsoon, from $29.4^{\circ}$ to $30.2^{\circ} \mathrm{C}$ in the second transitional period and from $27.5^{\circ}$ to $28.1^{\circ} \mathrm{C}$ in the west monsoon, while at the near bottom layer they vary from $29.6^{\circ}$ to $30.0^{\circ} \mathrm{C}$ in the first transitional period, from $29.0^{\circ}$ to $30.0^{\circ} \mathrm{C}$ in the full east monsoon, from $29.1^{\circ}$ to $29.3^{\circ} \mathrm{C}$ in the second transitional period and from $27.5^{\circ}$ to $28.1^{\circ} \mathrm{C}$ in the west monsoon. It is also interesting to note that the temperatures generally decrease toward the open sea, except during the west monsoon the opposite is true.

\section{DISCUSSIONS AND CONCLUSIONS}

Geographically, the water off Muara Karang is a small part of Jakarta Bay which belongs to the Jawa Sea region. Therefore, processes governing the hydrological conditions of the Jawa Sea will also influence to some extent those of the water off Muara Karang. To understand some of the 


\section{KASTORO \& SOEJATNO BIROWO}

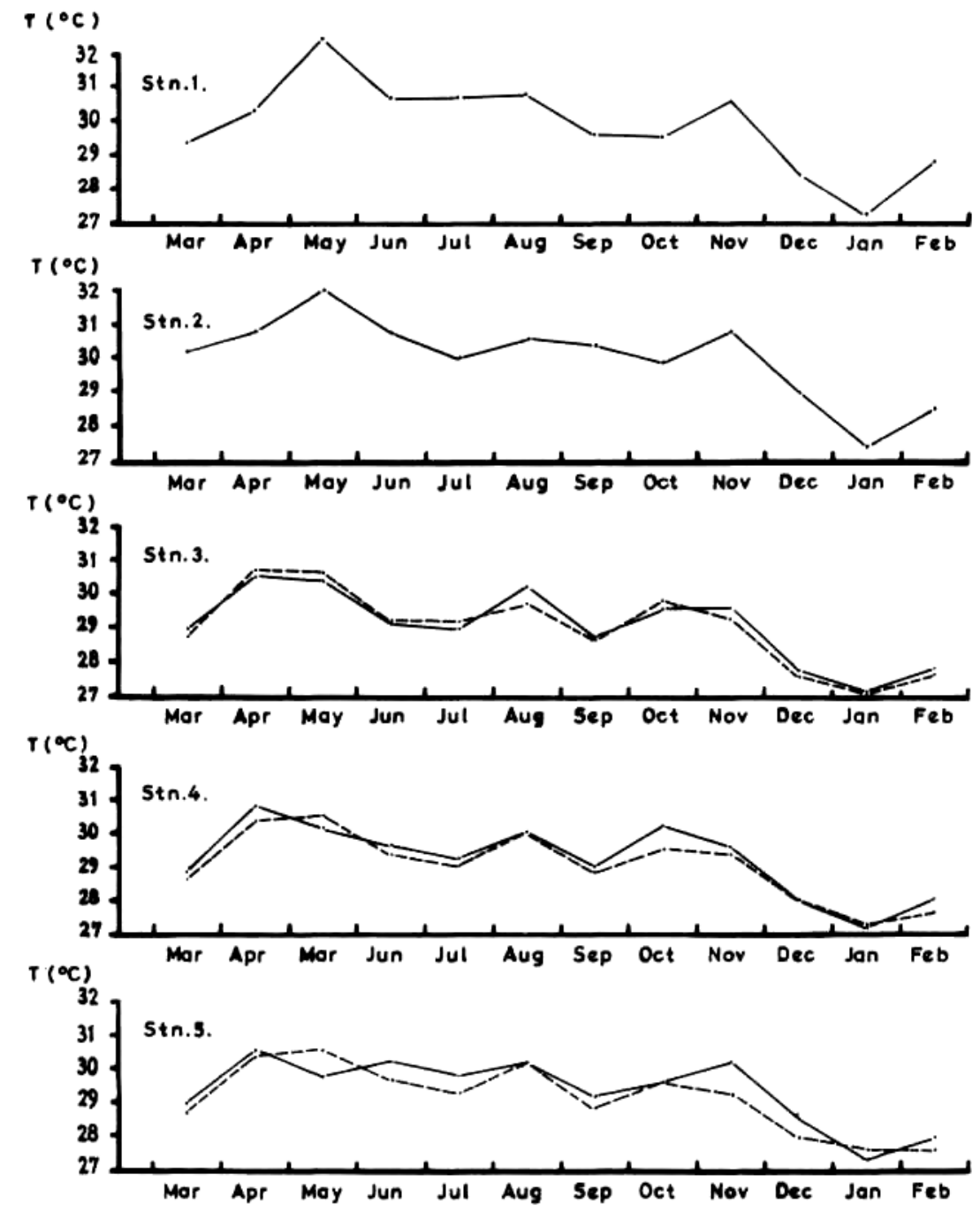




\section{TEMPERATURE OBSERVATIONS}

Fig. 2. (contd)

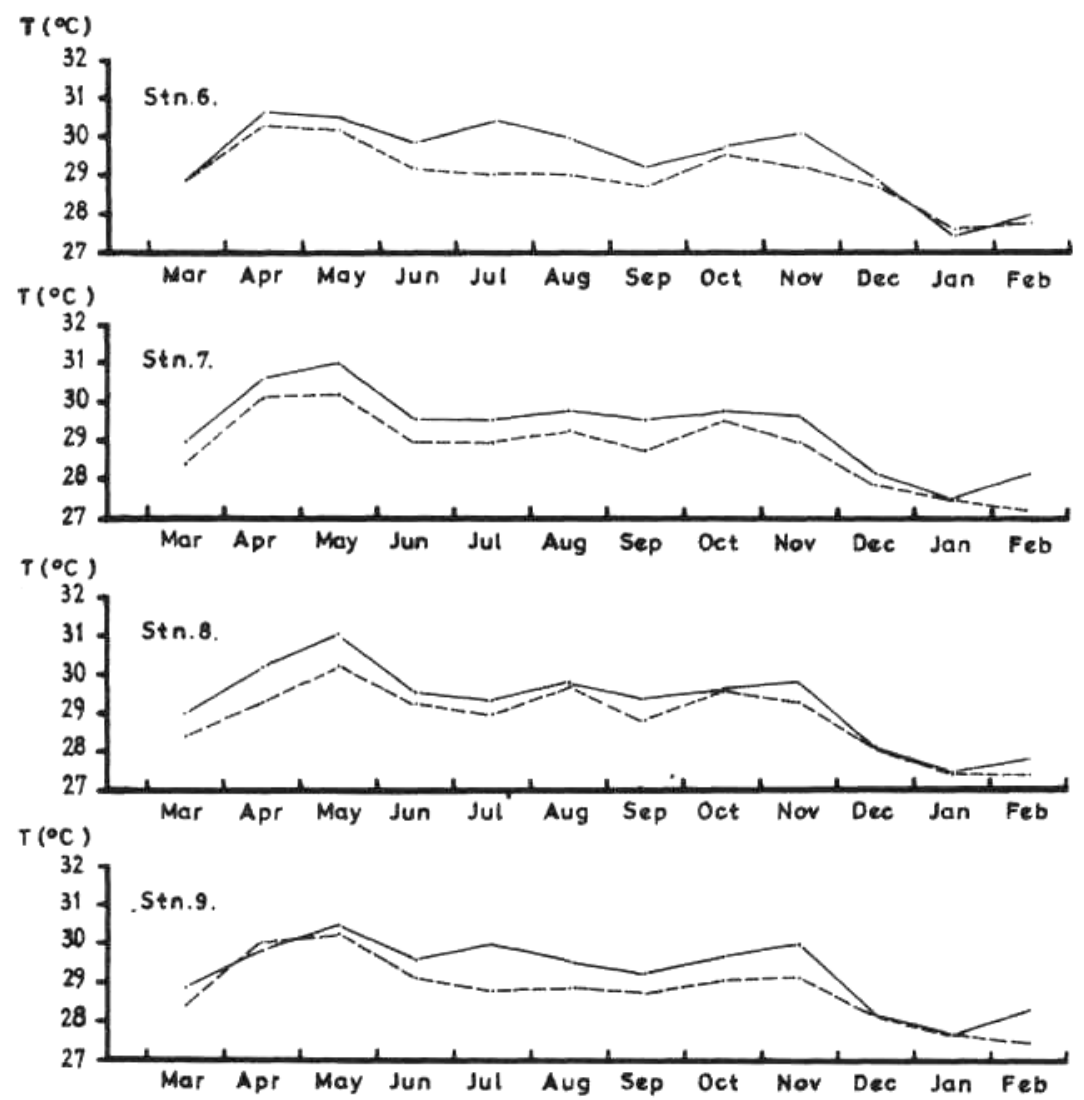

Figure 2. Monthly variations of temperature at stations 1 to 9 for surface (solid line) and subsurface (dashed line) 
hydrological changes observed in this area it is necessary to describe the general condition of the Jawa Sea.

Jakarta Bay is located on the northern coast of the Jawa Island. It has nearly a rectangle shape with a length (east to west) of 20 miles and with a maximum width of 9 miles. On the north the Bay is opened to the Jawa Sea. On the east, south and west it is bordered by the coast of Jawa. The bottom topography is regular and depths generally increases from the southern part northward. Depths range between 1 to $25 \mathrm{~m}$. There are several rivers entering the bay, namely Citarum River, Bekasi River, Muara Karang River and Angke River. Particularly during the rainy season much fresh water are flowing from the land side into the bay.

Several workers have studied the hydrological and climatological conditions of the Jawa Sea. WYRTKI (1957) concluded that the decrease in sea surface temperature around August is mainly caused by the condition of the energy balance, and in December to January by the affect of the west monsoon which brings relatively strong wind, and cool air masses. The distribution of the salinity has been studied, among others, by BERLAGE (1927), SOERIAATMADJA (1956), WYRTKI (1961), SJARIF (1959), RAHARDJO \& ILAHUDE (1965), KASTORO \& SOEJATNO BiRowO (1974). Some of them also discussed the temperature and current system in this region. These studies came to the conclusions that the hydrological properties and the current system in this region are strongly governed by the monsoons. Due to the west monsoon winds (December to February) and to the east monsoon winds (June to August) the surface temperature during the two seasons decrease to the value between $26.0^{\circ}$ to $27.0^{\circ} \mathrm{C}$. The decrease of these surface temperatures are caused by direct contact with the cold air masses, as well as by the increase of evaporation. During the transitional periods (March to May and September to November) the temperature is usually high (between $30.0^{\circ}$ and $31.0^{\circ} \mathrm{C}$ ) because of low evaporation.

The present study showed generally similar patterns of the monthly temperature variations with WYRTKI (1957) and KASTORO \&BIROWO (1974). The only difference is that the temperature in this study shows slightly higher values. During the first and the second transitional periods the temperature are relatively high (at the surface layer: $29.8^{\circ}$ to $30.8^{\circ} \mathrm{C}$, and $29.4^{\circ}$ to $30.2^{\circ} \mathrm{C}$; and near the bottom layer: $29.6^{\circ}$ to $30.0^{\circ} \mathrm{C}$, and $29.1^{\circ}$ to $29.3^{\circ} \mathrm{C}$ ) which might be due to the affects of the low wind speed and low evaporation rate. These two factors will generally result in a heating process, and as a consequence an increase in water temperature occurs everywhere in the Jawa Sea region, which reaches maximum values in May and November. This condition is in agreement to the result obtained in the present study as 


\section{TEMPERATURE OBSERVATIONS}

shown in Figure 2. During the east monsoon the temperature (at the surface layer: $29.6^{\circ}$ to $30.5^{\circ} \mathrm{C}$, and at the near bottom layer: 29.0 to $30.0^{\circ} \mathrm{C}$ ) are lower than those in the transitional periods. During the east monsoon strong wind usually prevails, which resulted in high evaporation. These factors might be the main cause of the decrease of the sea water temperature, particularly in the surface layer. During the west monsoon, a relatively strong wind with cool air masses prevails, which causes strong cooling. As a result, the temperature in this water can drop to values between $27.5^{\circ}$ to 28.1 C. During this time of the year the temperature is the lowest. At the same time, the increasing quantity of fresh water coming from the land into this area, due to the rainy season, might also strengthen the decrease in temperature. The proximity of the investigated area to the land mass of Jawa might have an affect to the increase in temperature of this water, which is shown as a gradual decrease of temperature toward the open sea (Figs; 3-10). The influences of temperature from water masses coming from the South China Sea and the Flores Sea, if any, are very small. It might be due to the fact that the surface layer temperature characteristic from the South China Sea and the Flores Sea, that enter the Jawa Sea, is nearly the same as those of the Jawa Sea. .

Some conclusions which might be worth to note are as follows:

1. The water temperature in this studies are slightly higher than those in the open sea. It is very clear, particularly for the values around coast line stations, compared with those in the open sea.

2. Distinct seasonal changes in temperature are found.

3. The meteorological conditions as well as the land mass effect seem to be the important factors influencing the temperature distribution in this area. 


\section{KASTORO \& SOEJATNO BIROWO}

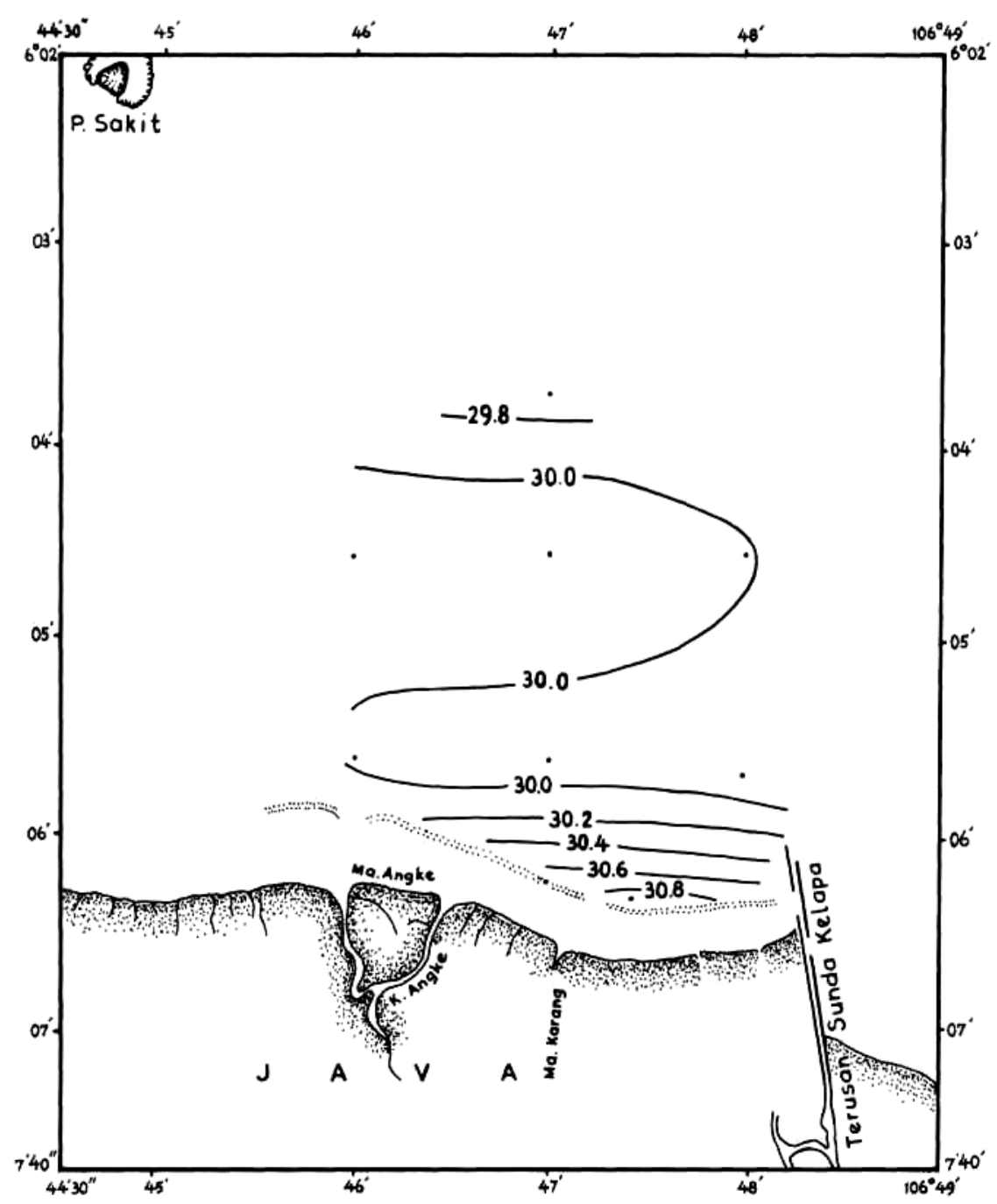

Figure 3. Horizontal distribution of temperature in the first transitional period at surface. 
TEMPERATURE OBSERVATIONS

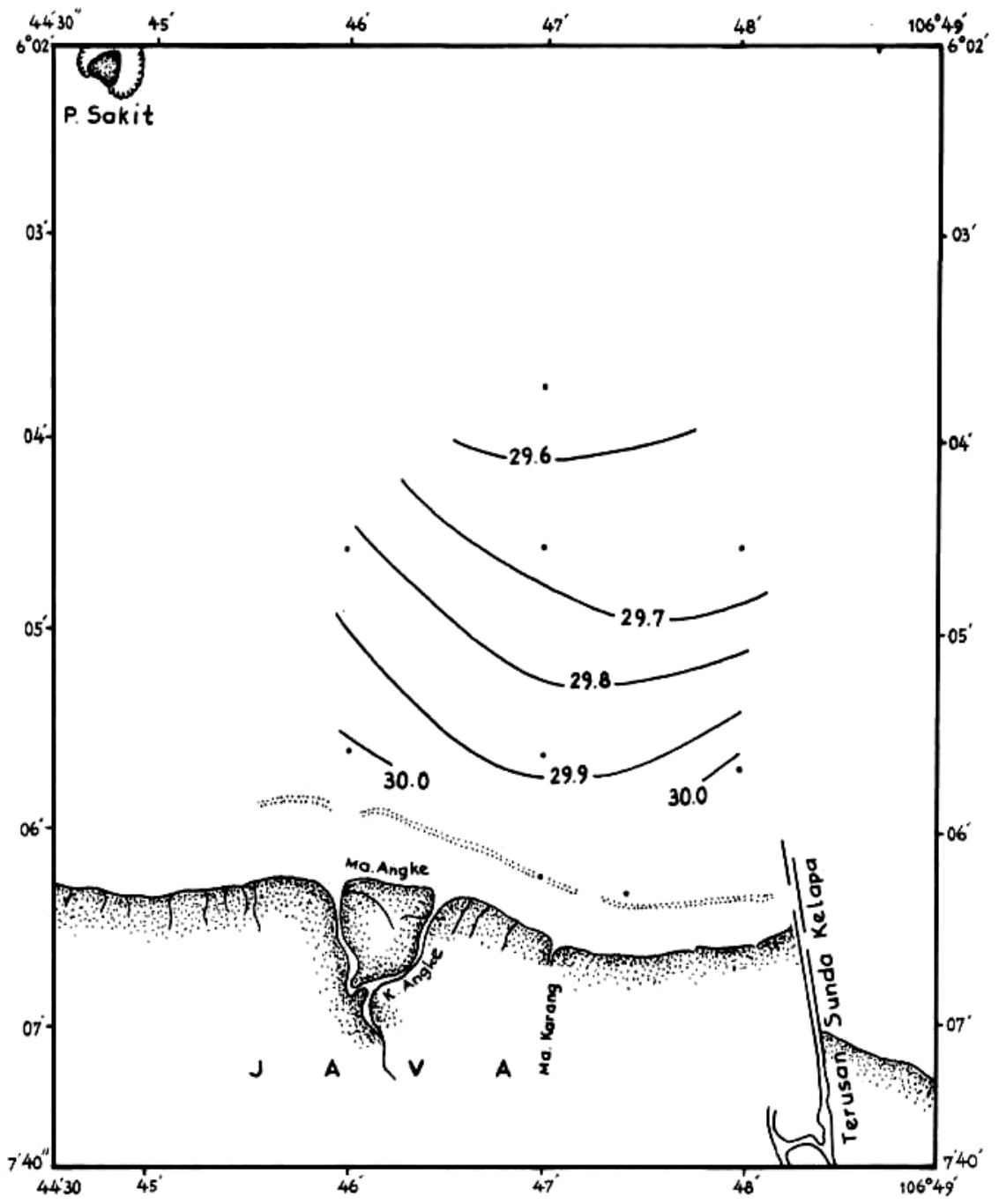

Figure 4. Horizontal distribution of temperature in the first transitional period at near bottom. 


\section{KASTORO \& SOEJATNO BIROWO}

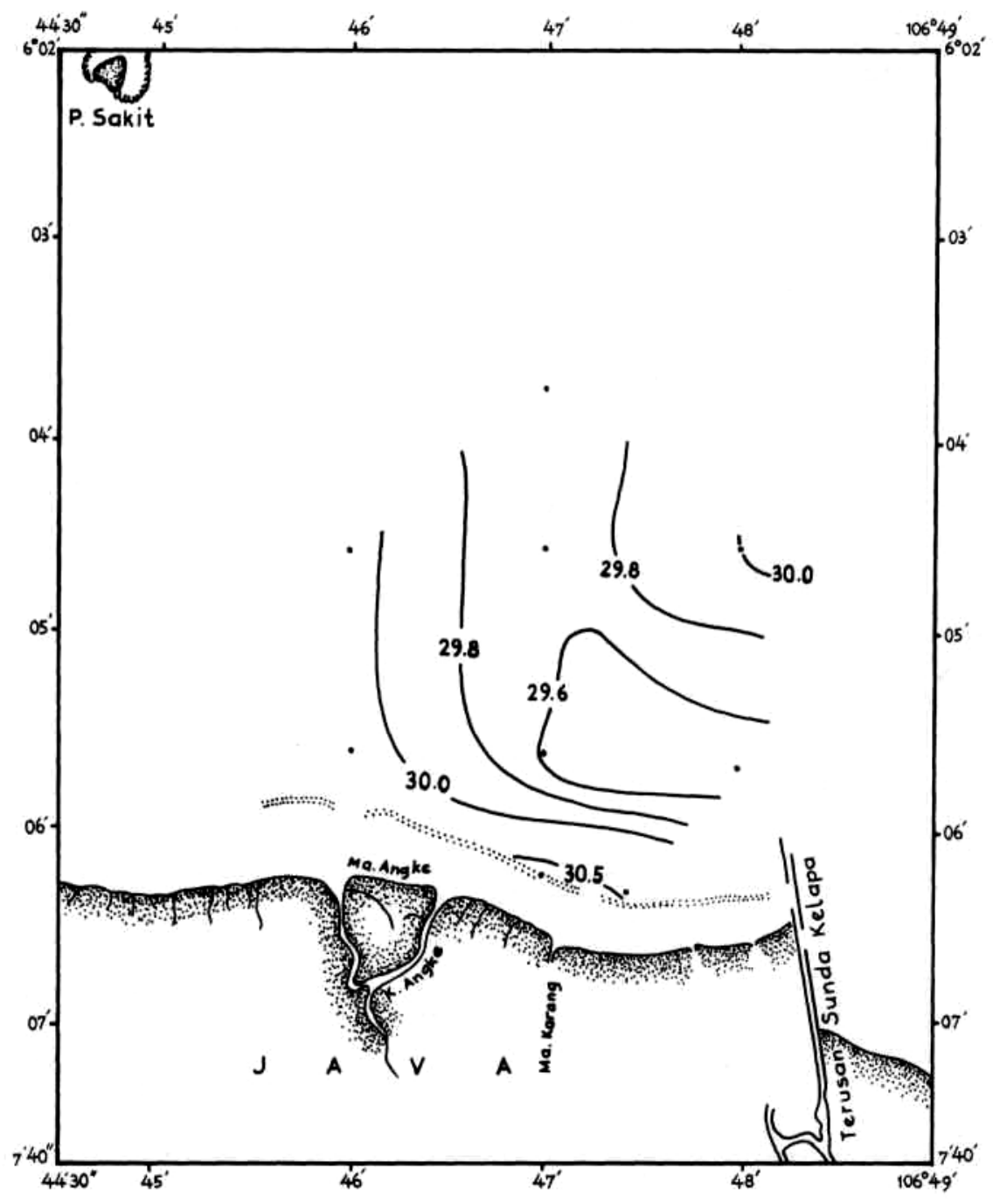

Figure 5. Horizontal distribution of temperature in the full east monsoon at surface. 
TEMPERATURE OBSERVATIONS

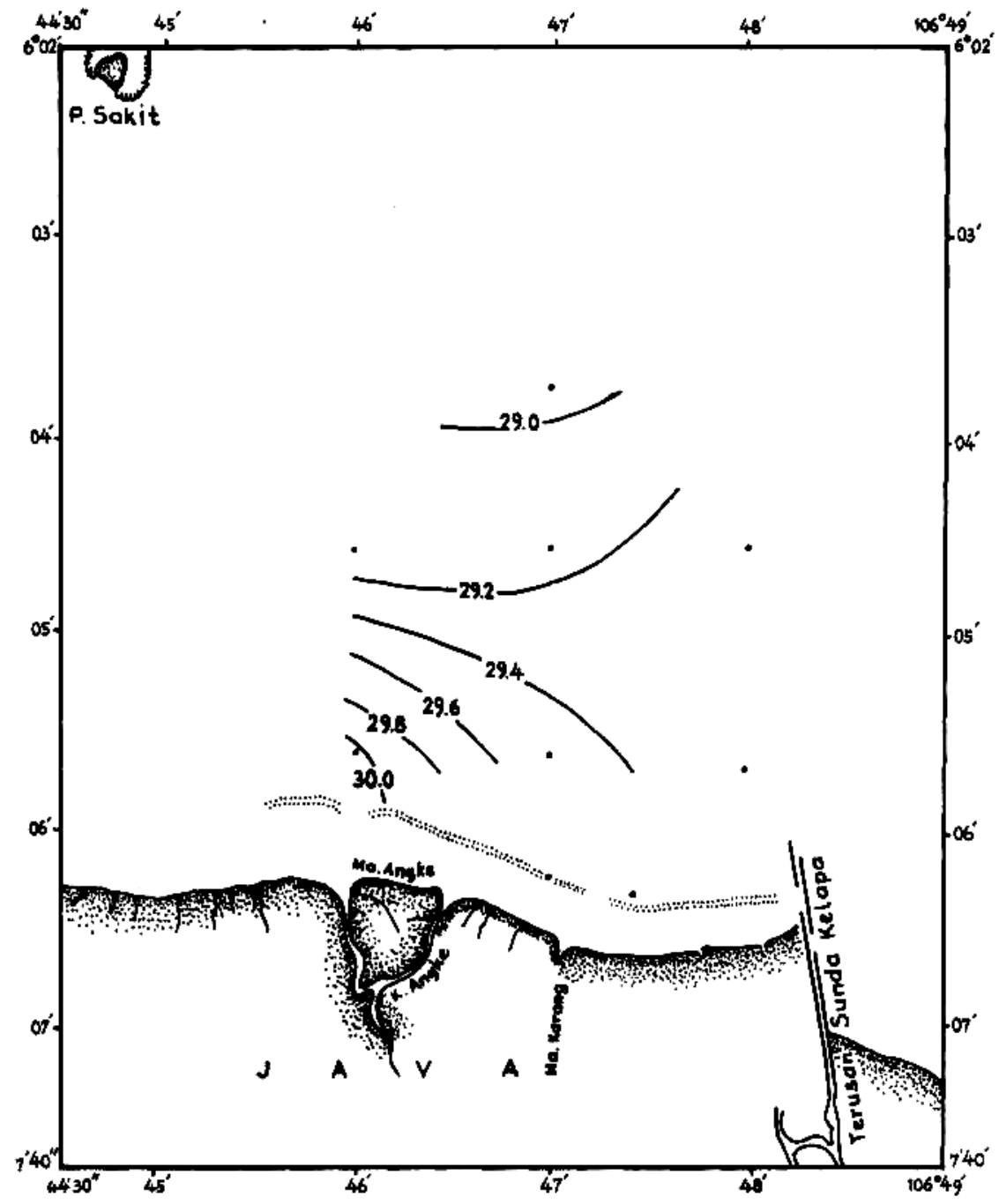

Figure 6. Horizontal distribution of temperature in the full east monsoon near bottom. 


\section{KASTORO \& SOEJATNO BIROWO}

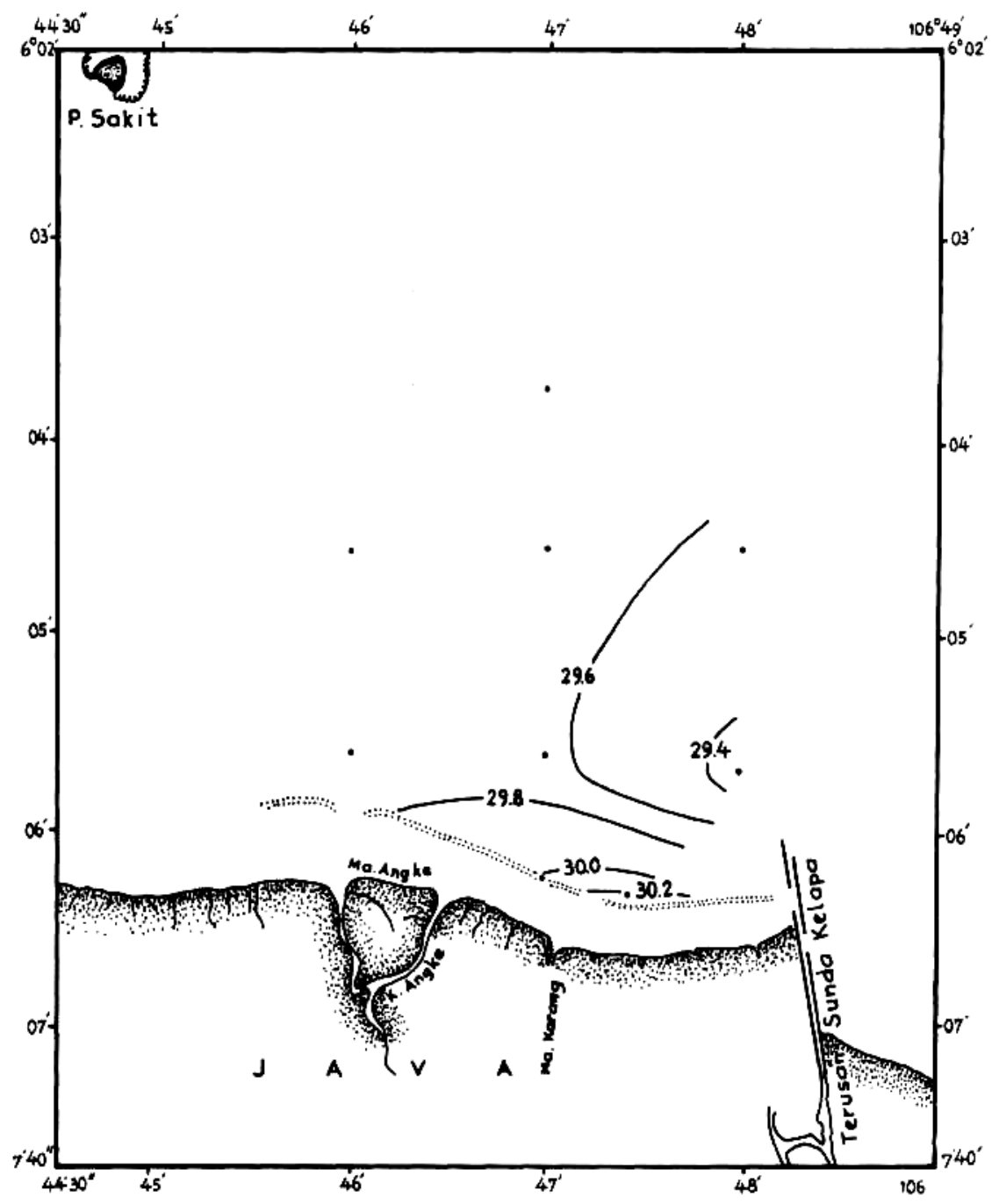

Figure 7. Horizontal distribution of temperature in the second transitional period at surface. 
TEMPERATURE OBSERVATIONS

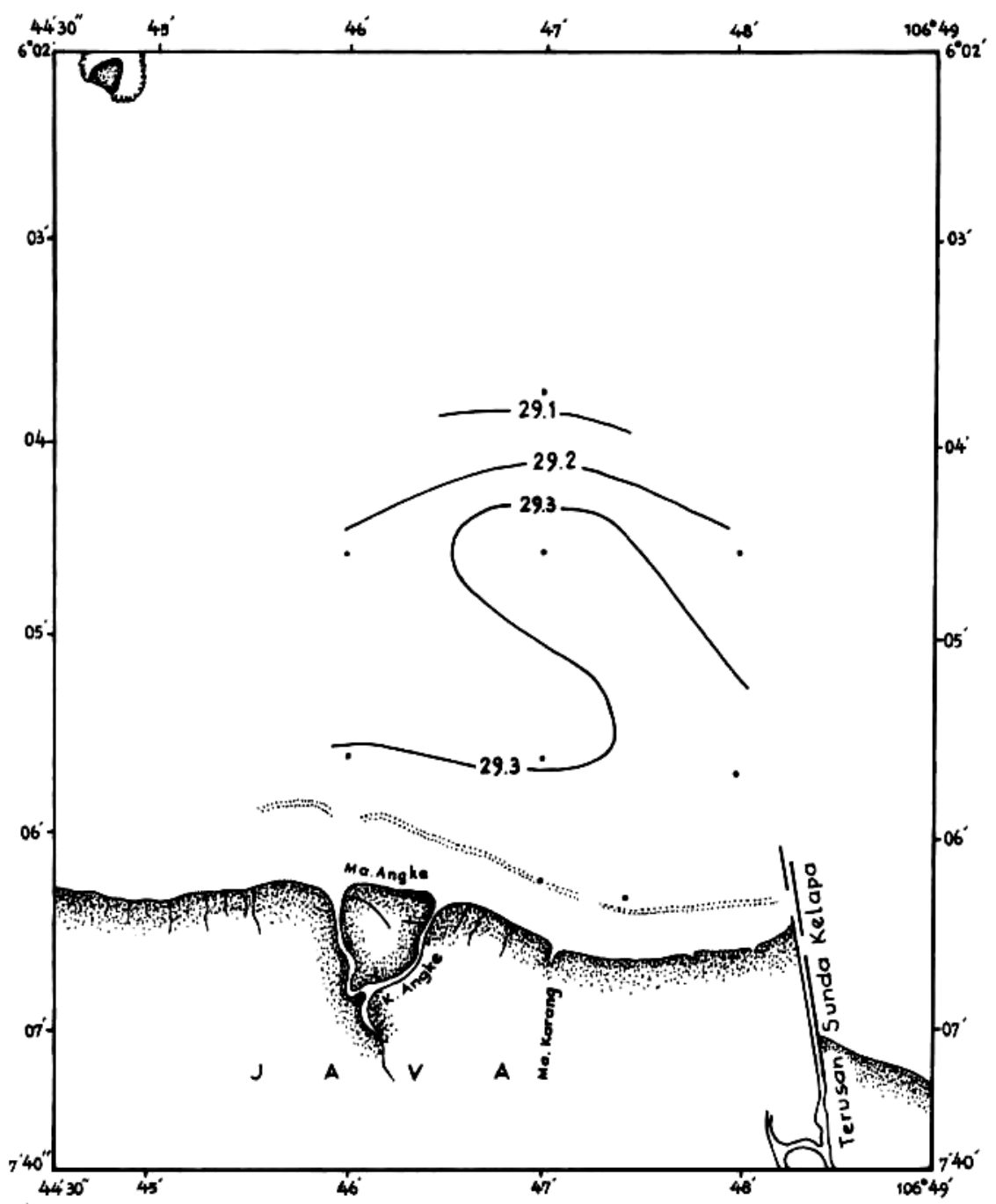

Figure 8. Horizontal distribution at temperature in the first transitional period at near bottom. 


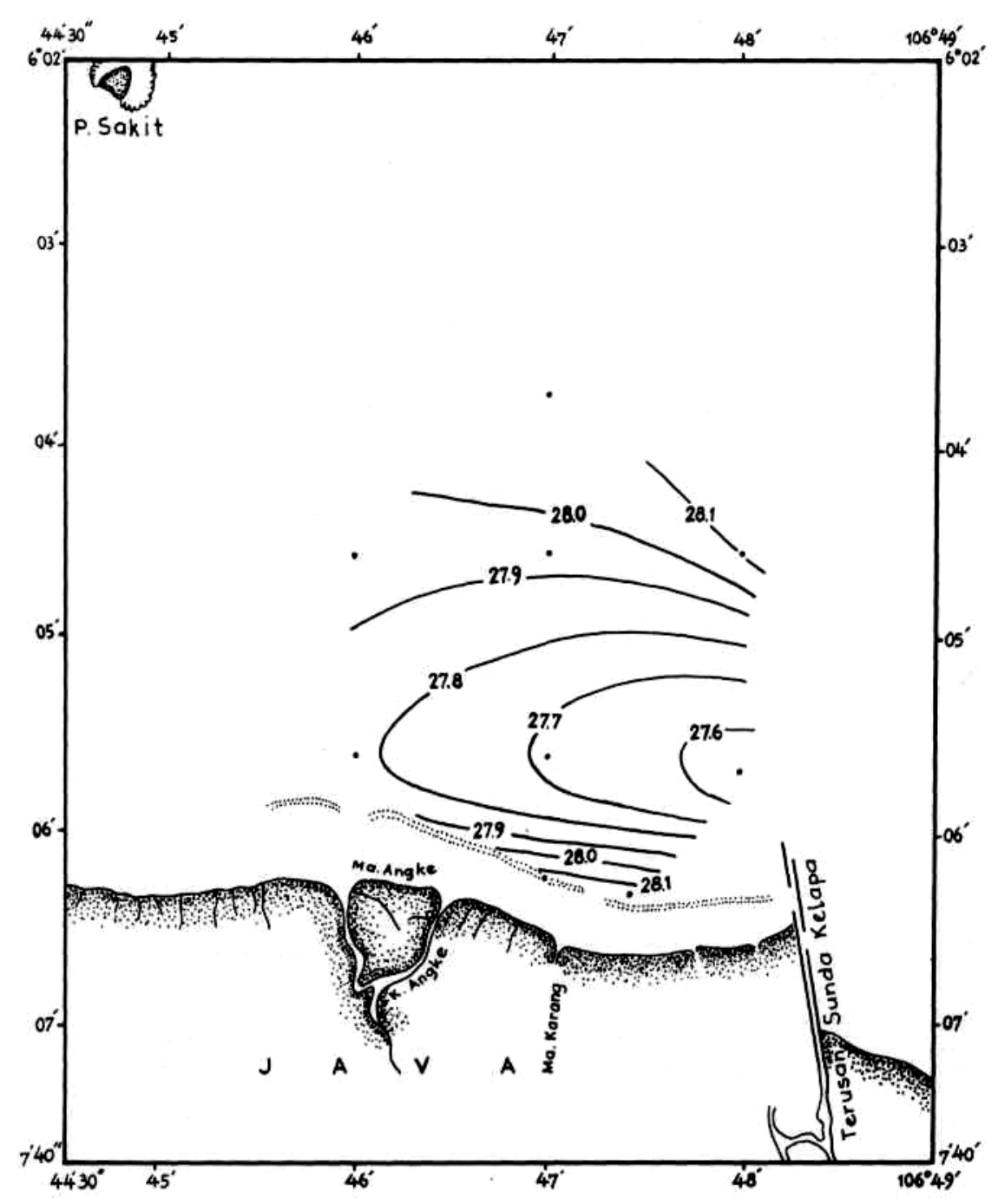

Figure 9. Horizontal distribution of temperature in the full west monsoon at surface. 
TEMPERATURE OBSERVATIONS

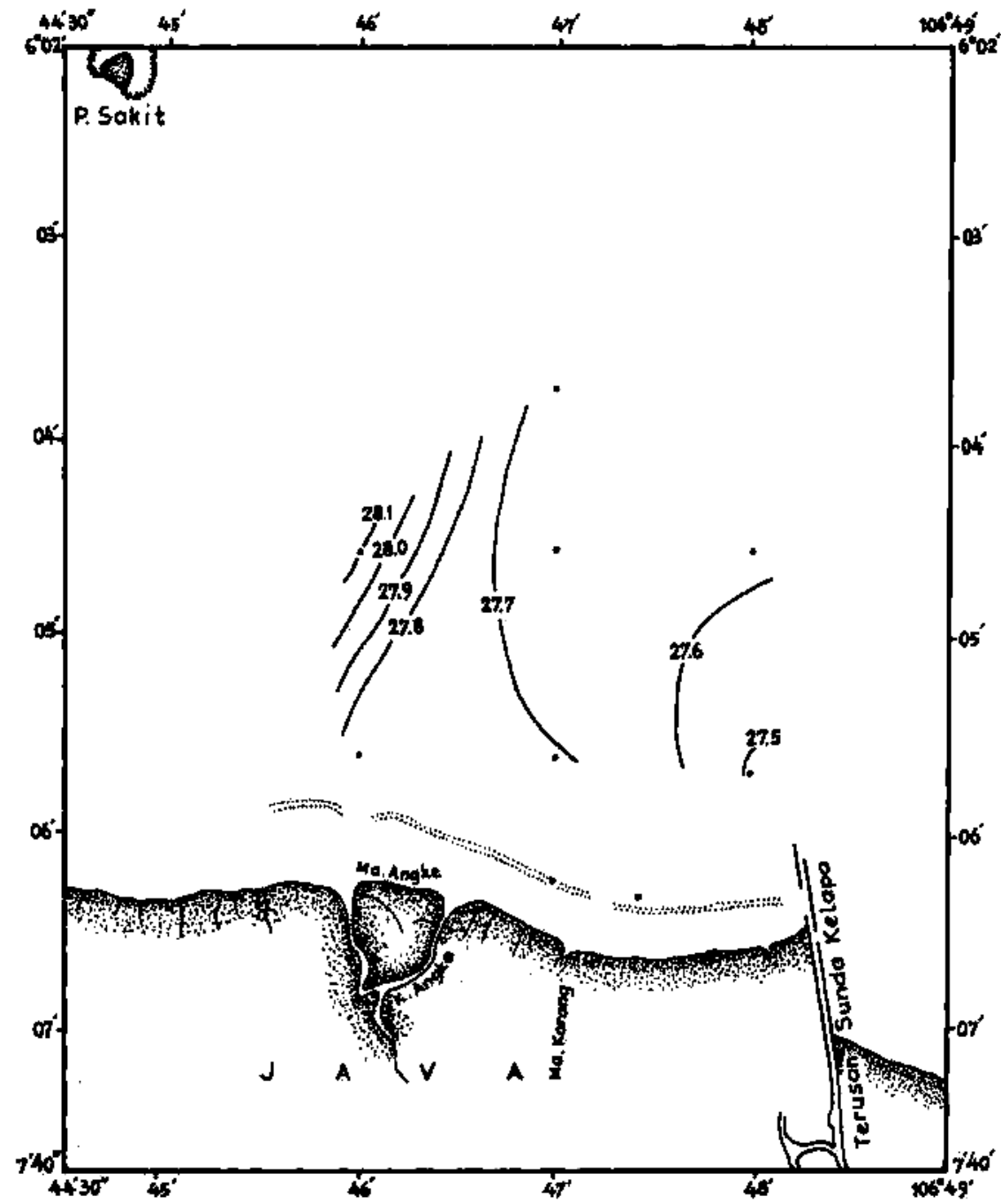

Figure 10. Horizontal distribution of temperature in the full west monsoon near bottom 


\section{KASTORO \& SOEJATNO BIROWO}

\section{REFERENCES}

BERLACE, H. P. Jr. 1927. Monsoon currents in the Java Sea and its entrances. Konin. Magnet. Obs. Batavia. Verhandelingen 19: 1 - 28.

KASTORO and S. BIROWO 1974. Seasonal changes in sea surface temperature and salinity around Pulau Anyer. Oseanologi di Indonesia No. 3: 1-10. (in Indonesian).

SJARIF, S. 1959. Seasonal fluctuations in the surface salinity along the coast of the southern part of Kalimantan (Borneo). Mar. Res. IndonesiaNo. 4: 25 pp.

SOERIAATMADJA, R. E. 1956. Seasonal fluctuations in the surface salinity off north coast of Java. Mar. Res. Indonesia. No. $1: 1 \quad 20$.

RAHARDJO, G. and A. G. ILAHUDE 1965. Temperature and salinity observations in the Java Sea. Baruna Expedition, Vol. 1:77-115.

WYRTKI, K. 1957. Precipitation, evaporation and energy exchange at the surface of the southeast Asian waters. Mar. Res. Indonesia 3: 1-40.

----1961. Physical oceanography of the southeast Asian waters. Naga Report 2, Scripps Inst.Oceanog., California: 1-163, 44 plates. 